in: Federico Fabbrini, Ernst Hirsch Ballin, Hans Somsen (ed.):

What Form of Government for the European Union and the

Eurozone? Oxford, Hart Publishing, 2015, 271-288.

15

\title{
Inter-Parliamentary Cooperation and its Challenges: The Case of Economic and Financial Governance
}

\author{
VALENTIN KREILINGER
}

\section{INTRODUCTION}

DHE TREATY ON Stability, Coordination and Governance (TSCG) has provided for the creation of an inter-parliamentary conference in order to discuss budgetary policies and other issues covered by that treaty. ${ }^{1}$ Fiscal and economic policy coordination in the Economic and Monetary Union (EMU) has become much more intense and takes place between the European Commission and national governments in the Council. The pressure put on Member States is based on a stronger legal framework, composed of the 'six-pack', the TSCG and the 'two-pack', ${ }^{2}$ and is visible in the functioning of the 'European Semester.' ${ }^{3}$ In this framework, parliamentary scrutiny of budgetary policies by individual national parliaments and by the European Parliament (EP) is limited. ${ }^{4}$

To address this state of affairs, increasing pressures have mounted to strengthen cooperation between the EP and national parliaments. According to many, interparliamentary cooperation and scrutiny could compensate national parliaments for the transfer of power from the national to the European level and for the transfer of power from national parliaments to their governments with respect to fiscal

\footnotetext{
I would like to thank Federico Fabbrini, the participants of the conference at Tilburg University in June 2014, and Christian Deubner for very helpful comments on earlier drafts of this chapter.

1 See Art 13 TSCG.

2 For a detailed account, see P Craig, 'Economic Governance and the Euro Crisis: Constitutional Architecture and Constitutional Implications' in M Adams, F Fabbrini and P Larouche (eds), The Constitutionalization of European Budgetary Constraints (Oxford, Hart Publishing, 2014).

3 The European Semester is foreseen by Art 2(a) Regulation 1466/97 amended by Regulation $1175 / 2011$.

${ }^{4}$ See D Chalmers, 'The European Redistributive State and a European Law of Struggle' (2012) 18 European Law Journal 667, 693 (stating that a 'zone of influence dominated by the Commission and ECOFIN is established, with political conflicts taking place within these, but the atrophying of local democracy leads to a hollowing out of domestic processes so that these become little more than administrative containers.)
} 
and economic policy. ${ }^{5}$ It could also allow the EP to exert influence in an area with little legislative activity and an only marginal role of the EP. However, interparliamentary cooperation in the area of economic and financial governance has met several challenges and has so far moved forward slowly.

The challenges of inter-parliamentary cooperation in economic and financial governance reflect those that have been encountered in foreign and security policy, ${ }^{6}$ but might be even more difficult to resolve, because the general relationship between the two parliamentary levels is still characterised by conflict, rather than cooperation. ${ }^{7}$ But the executive dominance in fiscal and economic policy coordination could put pressure on national parliaments and the EP to work together against their declining influence and 'exert countervailing power, both individually and collectively'. ${ }^{8}$ This chapter puts forward the idea that the purpose of a joint scrutiny inter-parliamentary cooperation should be to 'discuss' matters of common interest and to 'control' in areas with weak parliamentary scrutiny. However, inter-parliamentary settings should not 'decide', because assigning decision-making power to an inter-parliamentary conference would significantly alter the EU inter-institutional equilibrium.

The chapter is structured as follows: Section II describes inter-parliamentary cooperation as it is defined in the treaties and by inter-parliamentary practices. Although the Members of the European Parliament (MEPs) and members of national parliaments (MPs) meet regularly in organised settings, the meaning of inter-parliamentary cooperation is ill-defined and two contradictory concepts co-exist: Inter-parliamentary cooperation as 'centralised scrutiny' dominated by the $\mathrm{EP}$, with only very limited input by national parliaments; and inter-parliamentary cooperation as 'joint scrutiny' by national parliaments and the EP. ${ }^{9}$ Section III examines the concept of centralised scrutiny defended by the EP that aims at keeping inter-parliamentary cooperation weak. Section IV reviews the idea of joint scrutiny endorsed by many national parliaments, although not the national parliaments of all 28 Member States. ${ }^{10}$ Here, the cases of the parliaments of Denmark,

5 See, eg C Deubner, 'Stärkere Parlamente in der neuen WWU-Gouvernanz?' (2014) 37 integration 21, 44; A Maurer, From EMU to DEMU: The Democratic Legitimacy of the EU and the European Parliament (Rome, Istituto affari internazionali, 2013) 14; W Wessels, et al, Democratic Control in the Member States of the European Council and the Euro Zone Summits (European Parliament, 2012) 29.

6 A Herranz-Surrallés, 'The EU's Multilevel Parliamentary (Battle)Field: Inter-parliamentary Cooperation and Conflict in Foreign and Security Policy' (2014) 37 West European Politics 957.

7 K Neunreither, 'The European Parliament and National Parliaments: Conflict or Cooperation?' (2005) 11 Journal of Legislative Studies 466.

8 D Curtin, 'Challenging Executive Dominance in European Democracy' (2014) 77 Modern Law Review $1,30$.

9 I Cooper, 'Parliamentary Oversight of the EU after the Crisis: On the Creation of the "Article 13" Interparliamentary Conference’ (LUISS School of Government Working Papers, 2014) 2.

10 For the preferences of national parliaments and European institutions on Article 13 TSCG and its implementation, ibid. with the most recent account; C Deubner, The Difficult Role of Parliaments in the Reformed Governance of the Economic and Monetary Union (Brussels, Foundation of European Progressive Studies, 2013); V Kreilinger, The New Inter-parliamentary Conference on Economic and Financial Governance (Notre Europe-Jacques Delors Institute, 2013); and Maurer, From EMU to DEMU (n 5). 
France, Germany and Lithuania are analysed in more detail. Strong 'joint scrutiny' mechanisms are, for example, backed by the French Parliament, while the German Parliament prefers a weaker form of 'joint scrutiny'. This allows classifying parliaments according to three roles as inward-looking, passively cooperative or actively networking with respect to inter-parliamentary cooperation. Section V, finally, gives a summary of the findings of this chapter and an assessment of the prospects for inter-parliamentary cooperation in economic and financial governance.

\section{COOPERATION BETWEEN THE EUROPEAN PARLIAMENT AND NATIONAL PARLIAMENTS IN THE TREATIES AND IN PRACTICE}

According to Article 12 TEU national parliaments 'contribute actively to the good functioning of the Union ... by taking part in the inter-parliamentary cooperation between national Parliaments and with the European Parliament. ${ }^{11}$ The precise legal basis for inter-parliamentary cooperation can be found in Protocol No 1 on the Role of National Parliaments annexed to the EU treaties: 'the organisation and promotion of effective and regular inter-parliamentary cooperation within the Union shall be determined by the European Parliament and National Parliaments. ${ }^{12}$ Article 10 of Protocol No 1 specifies that a

conference of Parliamentary Committees for Union Affairs ... shall ... promote the exchange of information and best practice between National Parliaments and the European Parliament, including their special committees. It may also organise interparliamentary conferences on specific topics ... Contributions from the conference shall not bind National Parliaments and shall not prejudge their positions. ${ }^{13}$

This provision of the Protocol recognises the Conference of Parliamentary Committees for Union Affairs of Parliaments of the EU (COSAC) which was established in 1989. Based on the COSAC model two new policy-specific inter-parliamentary conferences were created recently. On the one hand, the Inter-parliamentary Conference on Common Foreign Security Policy (CFSP) and Common Security and Defence Policy (CSDP) substituted the Assembly of the West European Union (WEU) in 2012. On the other hand, the need for better cooperation between national parliaments and the EP with respect to the EMU was acknowledged by the TSCG, ${ }^{14}$ and it prompted the creation of an interparliamentary conference which had its first meeting in October 2013.

Article 13 TSCG is the product of the intergovernmental negotiations and has undergone significant changes during the negotiating process, revealing the difficulties met by the Member States in reaching an agreement on this point. The original objective of the treaty article was that national MPs meet regularly and

11 Art 12 TEU.

12 Art 9, Protocol No 1 on the Role of National Parliaments in the European Union annexed to the European Union Treaties.

13 ibid Art 10.

14 See above (n 1$)$. 
that this would happen in close association with the EP. Article 13 was completely revised twice and only the later drafts of the treaty drew a link to the existing inter-parliamentary structures. ${ }^{15}$ Member States may have included the article in the treaty in order to facilitate the national ratification processes of the TSCG. The final wording of Article 13 agreed by the Contracting Parties is the following:

As provided for in Title II of Protocol (No 1) on the role of national Parliaments in the European Union annexed to the European Union Treaties, the European Parliament and the national Parliaments of the Contracting Parties will together determine the organisation and promotion of a conference of representatives of the relevant committees of the European Parliament and representatives of the relevant committees of national Parliaments in order to discuss budgetary policies and other issues covered by this Treaty. ${ }^{16}$

In the national ratification processes of the TSCG and in discussions about how to achieve a 'genuine EMU' the question of the implementation of Article 13 TSCG emerged on the agenda and parliaments started to address the issue. Both chairpersons of European Affairs Committees and Speakers of Parliaments held informal ad hoc meetings in sub-groups and tried to coordinate their positions. After many actors had articulated their preferences, sometimes both individually and collectively, it was the 'Speakers' Conference' in April 2013 (the annual meeting of the Speakers of all EU parliaments) that agreed on a compromise about the organisation of the inter-parliamentary conference. ${ }^{17}$ Thus the conclusions of the Speakers' Conference provided the basis for bringing Article 13 TSCG into practice in October 2013. Since then the inter-parliamentary conference has discussed whether it should adopt Rules of Procedure and possible provisions to be included into them: the Parliament of Lithuania presented a draft ${ }^{18}$ which was not endorsed by the conference, the following Presidency (Greece) asked all parliaments for input, and at the September 2014 meeting (organised by the Italian Parliament) the internal organisation was an item on the agenda and discussed at the interparliamentary conference, but no agreement was reached and further discussions were postponed until 2015.

Many analysts have assessed inter-parliamentary cooperation as beneficial, both from a rationalist and a normative perspective: inter-parliamentary cooperation could reduce informational asymmetries, favour the exchange of specialised knowledge, facilitate policy formulation, and foster mutual understanding and a

15 For a detailed discussion of the drafting of the TSCG, see V Kreilinger, The Making of a New Treaty: Six Rounds of Political Bargaining (Notre Europe-Jacques Delors Institute, 2012).

16 See above (n 1 ).

17 Conference of Speakers of European Union Parliaments, 'Presidency Conclusions-Nicosia, 21-23 April 2014' available at: www.ipex.eu/IPEXL-WEB/dossier/files/download/082dbcc53dbcb6ed 013e3b68418b5327.do. For an analysis of the compromise, see Kreilinger, The Making of a New Treaty (n 15) 14.

18 Parliament of Lithuania, 'Draft Rules of Procedure of the Interparliamentary Conference on Economic and Financial Governance of the European Union', 2013. 
transnational public debate. ${ }^{19}$ Inter-parliamentary cooperation could not only contribute to reducing the democratic deficit by giving a collective voice to parliaments, but the exchange of information and best practices for individual scrutiny could also lead to stronger parliamentary control of national governments and EU institutions. This would strengthen both elements of the dual legitimacy on which the political system of the EU relies- the democratic institutions of the Member States and the directly elected EP. ${ }^{20}$ However, the TSCG and the Treaty establishing a European Stability Mechanism (ESM) do 'little or nothing to anchor new regulatory functions for the Union in democratic institutions. ${ }^{21}$

At the same time, 'the intergovernmental logic brings with it an interparliamentary balancing':22 the main theoretical rationale behind resorting to inter-parliamentary cooperation in economic and financial governance lies in the use of intergovernmental legal instruments in that area. More far-reaching concepts for multi-level parliamentarism insist that: 'The dominance of the member state governments in the European Council needs to be balanced with an equally strong voice of parliamentary representation. ${ }^{23}$ If Member States had not resorted to the intergovernmental or to the 'Union method', ${ }^{24}$ economic and financial affairs would be governed by the Community method and the EP would be entirely responsible for democratic control..$^{25}$

In practice, there are some challenges for inter-parliamentary cooperation. ${ }^{26}$ The participation rates of national parliaments in such conferences illustrate the ambiguous interest of MPs in European affairs: COSAC meetings from 2009 to 2013 show a considerable variation across EU Member States and this assessment was confirmed for the inter-parliamentary conference on economic and

19 See especially, Herranz-Surrallés, 'The EU's Multilevel Parliamentary (Battle)Field' (n 6) 2; A Benz, 'Linking Multiple Demoi: Inter-parliamentary Relations in the EU' (2011) 12 Hagener Online-Beiträge zu den Europäischen Verfassungswissenschaften 11; C Kraft-Kasack, 'Transnational Parliamentary Assemblies: A Remedy for the Democratic Deficit of International Governance?' (2008) 31 West European Politics 534; K Neunreither, 'The Democratic Deficit of the European Union: Towards Closer Cooperation between the European Parliament and the National Parliaments' (1994) 29 Government and Opposition 299.

20 See, eg Neunreither, 'The Democratic Deficit' (n 19).

${ }^{21} \mathrm{M}$ Dawson and F de Witte, 'Constitutional Balance in the EU after the Euro-Crisis' (2013) 76 Modern Law Review 817, 834.

22 S Fabbrini, Intergovermentalism and its Outcomes: The Implications of the Euro Crisis on the European Union (LUISS School of Government Working Papers Series, 2013) 12.

${ }^{23}$ J Neyer, 'Justified Multi-level Parliamentarism: Situating National Parliaments in the European Polity' (2014) 20 Journal of Legislative Studies 125, 135.

24 A Merkel, Speech at the opening ceremony of the 61st academic year of the College of Europe in Bruges on 2 November 2010.

${ }^{25}$ On the Community method, see for a summary, eg R Dehousse, La méthode communautaire, système opérationnel "par défaut" de l'UE (Notre Europe-Jacques Delors Institute, 2013).

${ }^{26} \mathrm{O}$ Costa and M Latek 'Paradoxes and Limits of Interparliamentary Cooperation in the European Union' (2001) 23 Journal of European Integration 139; T Raunio, 'National Parliaments and European Integration: What we know and Agenda for Future Research' (2009) 15 Journal of Legislative Studies 317. 
financial governance. ${ }^{27}$ Thus relations between national parliaments have so far 'not develop [ed] into a balanced multilateral interplay including parliaments from all member states on the same footing. ${ }^{28}$

In addition to that, two different concepts of inter-parliamentary cooperation coexist: the key question is whether there should be centralised scrutiny or joint scrutiny. 'Centralised scrutiny' means that inter-parliamentary cooperation is dominated by the EP, with only very limited input by national parliaments; the competing concept is inter-parliamentary cooperation as 'joint scrutiny' by national parliaments and the EP. ${ }^{29}$

These different concepts reflect disagreement about which functions an interparliamentary conference should fulfil. Disagreement typically centres on the actual purpose of inter-parliamentary cooperation: Should it decide? Should it control? Should it discuss? Moreover, it concerns basic issues such as the formal weight to be given to the two parliamentary levels: should the EP delegation have as many seats as each of the national parliaments or should it have more? ${ }^{30}$

The underlying explanation of the profound disagreements between national parliaments and the EP is a mismatch between the daily EU policy-making and formal treaty powers which lead to 'overlapping authority claims' ${ }^{31}$ an incremental and informal empowerment of the EP, even in economic and financial governance, clashes with national parliaments and their constitutional role linked to intergovernmental treaties and their domestic role in controlling national governments. This prevents sharing the scrutiny tasks between national parliaments and the EP in EMU governance. ${ }^{32}$

\section{INTER-PARLIAMENTARY COOPERATION AS CENTRALISED SCRUTINY DOMINATED BY THE EUROPEAN PARLIAMENT}

The EP has traditionally been sceptical about enhancing the role of national parliaments, fearing that this might undermine its position. ${ }^{33}$ In an own-initiative report on a genuine EMU, the EP stated in November 2012 that only itself, 'as parliamentary body at the Union level for a reinforced and democratic EMU

27 For data on COSAC: Kreilinger, The New Inter-parliamentary Conference (n 10) 5. For data on the first inter-parliamentary conference on economic and financial governance, V Kreilinger, 'Possibilities for Upgrading Inter-parliamentary Cooperation after the 2014 European Elections' (2014) 23 Polish Quarterly of International Affairs 57, 59.

28 Benz, 'Linking Multiple Demoi' (n 19) 11.

29 Cooper, 'Parliamentary Oversight of the EU' (n 9) 2.

30 Kreilinger, 'Possibilities for Upgrading Inter-parliamentary Cooperation' (n 27) 58.

31 Herranz-Surrallés (n 6) 15.

32 See Deubner, 'Stärkere Parlamente in der neuen WWU-Gouvernanz?' (n 5) 37.

33 See, eg B Crum and JE Fossum, 'Conclusion: Towards a Democratic Multilevel Parliamentary Field?' in B Crum and JE Fossum (eds), Practices of Inter-parliamentary Coordination in International Politics the European Union and Beyond (Colchester, ECPR Press, 2013) 255. 
governance, ${ }^{34}$ had full democratic legitimacy to exercise control in that area. The report, drafted by Marianne Thyssen MEP, described the possibility of creating a mixed parliamentary body as 'both ineffective and illegitimate':

While reaffirming its intention to intensify the cooperation with national parliaments on the basis of Protocol No 1, [it] stresses that such a cooperation should not be seen as the creation of a new mixed parliamentary body which would be both ineffective and illegitimate on a democratic and constitutional point of view; [it also] stresses the full legitimacy of the European Parliament, as parliamentary body at the Union level for a reinforced and democratic EMU governance. ${ }^{35}$

In its blueprint for a deep and genuine EMU, also published in November 2012, the European Commission took a critical view on inter-parliamentary cooperation, too, and echoed the Parliament's view by stating:

The role of national parliaments will always remain crucial in ensuring legitimacy of Member States' action ... Cooperation between the European Parliament and national parliaments is also valuable: it builds up mutual understanding and common ownership for EMU as a multilevel governance system ... Inter-parliamentary cooperation as such does not, however, ensure democratic legitimacy for EU decisions. That requires a parliamentary assembly representatively composed in which votes can be taken. The European Parliament, and only it, is that assembly for the EU and hence for the euro. ${ }^{36}$

The EU supranational institutions thus reject the view that cooperation between the EP and national parliaments may provide democratic legitimacy for EMUrelated decisions. The final report 'towards a genuine Economic and Monetary Union' drafted by the President of the European Council puts the EP at the centre of ensuring democratic legitimacy and accountability. At the end of the process, the European Council conclusions of 13-14 December 2012 affirm that: 'The European Parliament and national parliaments will determine together the organisation and promotion of a conference of their representatives to discuss EMU related issues. ${ }^{37}$ This is exactly the wording of Article 13 TSCG as it had emerged in January $2012 .{ }^{38}$

The concept of inter-parliamentary cooperation as centralised scrutiny dominated by the EP has gained traction at the EU level. According to this reasoning only the EP is able 'to stress the points of convergence and the shared interests amongst the parliamentarians and citizens of different Member States, instead of aiming at achieving exclusively national interests. ${ }^{39}$ The President of the European

\footnotetext{
${ }^{34}$ European Parliament, Report with recommendations to the Commission on the report of the Presidents of the European Council, the European Commission, the European Central Bank and the Eurogroup 'Towards a genuine Economic and Monetary Union' (19 November 2012, 2012/2151(INI)) 19.

35 ibid.

36 European Commission, 'A blueprint for a deep and genuine economic and monetary union: Launching a European Debate', 28 November 2012, COM (2012) 777 final 35.

37 European Council, Conclusions of 13-14 December (2012, EUCO 205/12).

38 See Kreilinger (n 15).

${ }^{39} \mathrm{C}$ Fasone, 'The struggle of the European Parliament to participate in the new Economic Governance’ EUI Working Paper RSCAS 45/2012, 18.
} 
affairs committee of the French Senate stressed that the EP 'has put pressure on other EU institutions to convince them that parliamentary oversight of the new governance is primarily ensured by itself'. ${ }^{40}$ During the negotiations on the set-up of the inter-parliamentary conference on economic and financial governance, that are still not completed, the EP 'pursues the sometimes contradictory goals of keeping the conference weak, but at the same time maintaining [or securing] a privileged position for itself in the new structure. ${ }^{41}$

In addition to that, in 2014 the EP has also considered a modification of its own internal organisation in order to respond to the needs of fiscal and economic policy coordination: possible options that have been discussed with respect to the structure and modalities for euro area governance within the EP include additional resources for euro area scrutiny within the existing economic and monetary affairs committee or a new parliamentary structure (an 'EMU subcommittee') entrusted with non-legislative scrutiny tasks. ${ }^{42}$

\section{INTER-PARLIAMENTARY COOPERATION AS JOINT SCRUTINY BY THE EUROPEAN PARLIAMENT AND NATIONAL PARLIAMENTS}

\section{A. The Argument for Joint Scrutiny in Financial and Economic Governance}

The first report 'towards a genuine Economic and Monetary Union' in June 2012 floated the idea of 'joint [inter-parliamentary] decision-making' ${ }^{43}$ but the later reports lowered the level of ambition and only called for an increase in 'the level of cooperation between national parliaments and the European Parliament. ${ }^{4}$ There are, however, many decisions concerning economic and fiscal policy coordination in the EU that are either taken in intergovernmental settings without proper control by parliament or build upon recommendations of the European Commission in the context of the European Semester that restrict the policy options that are available in terms of the budgetary and economic policy choices at the national level. ${ }^{45}$ Or, in other words, 'the austerity drive, in particular through

40 Sénat français, 'Compte rendu de la Commission des affaires européennes' (31 January 2013) available at: www.senat.fr/compte-rendu-commissions/20130128/europ.html. Translated by the author.

41 Cooper (n 9) 2.

$42 \mathrm{~S}$ Bowles, 'Structure and modalities within the Parliament for euro area governance in the next legislature, Letter to Martin Schulz' (2014) available at: sylvie-goulard.eu/articles2014/Annex3a-Chair-s-Announcements-ECON-structure.pdf.

43 European Council President, 'Towards a Genuine Economic and Monetary Union' (26 June 2012) 6.

44 European Council President, 'Towards a Genuine Economic and Monetary Union. Interim Report' (12 October 2012) 8.

${ }^{45}$ See, eg Chalmers, 'The European Redistributive State' (n 4); R Dehousse and L Boussaguet, 'L'impact de la crise sur la gouvernance européenne' (2014) nº149 Pouvoirs 7; FW Scharpf, 'Monetary Union, Fiscal Crisis and the Pre-emption of Democracy' (2011) 2 Zeitschrift für Staats- und Europawissenschaften 163 . 
the obligations provided for under the European Semester ... sidelines national parliaments from the budgetary control that constitutes their most traditional and symbolic prerogative. ${ }^{46}$

When fiscal and economic policies have become more closely coordinated at the European level, but continue to be national policies and not a common and single EU policy, parliamentary control in the EMU can neither be exercised solely by the EP, nor individually by each national parliament holding its government accountable. Parliaments in the EU 'are increasingly orientated to one another; each is becoming an intrinsic part of the others' operating environment.. ${ }^{47}$ Thus joint scrutiny by the EP and national parliaments has been voiced as a solution, ${ }^{48}$ because many experts fear that if the strongest national parliament(s) served as the benchmark for the individual scrutiny mechanisms to be adopted by other national parliaments, 'the EMU might become altogether ungovernable. ${ }^{49} \mathrm{~A}$ feasible solution is deeply informed oversight in an inter-parliamentary conferencelinked to the European Semester, to European Council meetings (and the Euro summits at their margins) and to key Euro group meetings — with an awareness of the functioning of economic and financial governance and allowing for some room of manoeuvre for the executive(s). ${ }^{50}$ Inter-parliamentary cooperation has the advantage of combining both parliamentary levels. If the German Finance Minister acts at the EU level in the Eurogroup or the Board of the European Stability Mechanism, he will obviously be under scrutiny of the Bundestag, but there could also be hearings by an inter-parliamentary body which would include MPs from other national parliaments as well as MEPs.

Some decisions in the EMU are taken without proper parliamentary control at any level (this concerns the ESM, the Eurogroup, European Council meetings or euro area summits, and the European Central Bank), ${ }^{51}$ even though the heads of all these bodies appear before the EP, either in plenary or in the economic and monetary affairs committee. ${ }^{52}$ An inter-parliamentary arena, where MPs and MEPs meet regularly, as a place for discussion and as a meeting point between

46 Dawson and de Witte, 'Constitutional Balance in the EU' (n 21) 827.

47 Crum and Fossum, 'Conclusion' (n 33) 252.

48 Most recently the conclusions of the Speakers' Conference in Nicosia (April 2013) and the working paper issued after a meeting of a sub-group of speakers in Luxembourg (January 2013) make proposals that follow the idea of 'joint scrutiny'.

${ }^{49}$ For a summary of this view, not shared by the author himself, see Deubner, The Difficult Role of Parliaments (n 10) 35.

50 See C Hefftler et al, National Parliaments: Their Emerging Control over the European Council (Notre Europe-Jacques Delors Institute, 2013) 12.

51 The ESM treaty does not mention the EP and only mentions national parliaments in a commitment to provide them with the annual report of its board of auditors in Art 30 ESM (Dawson and de Witte (n 21) 833). See also Wessels et al, Democratic Control (n 5). For a more detailed account of the EMU institutional framework, see A De Streel, 'The Evolution of the EU Economic Governance since the Treaty of Maastricht: An Unfinished Task' (2013) 20 Maastricht Journal of European and Comparative Law 336, 353.

52 Kreilinger (n 10) 14. 
the democratically legitimised institutions of the EU level and the national level, could collectively fulfil this control function, even though the EP is apparently situated in 'a complex pattern of cooperation and competition with national parliaments. ${ }^{53}$ The possibilities at such a conference to discuss and to exchange best practices could also provide a remedy against the information asymmetry from which national parliaments suffer vis-à-vis their governments. ${ }^{54}$ Such an inter-parliamentary conference, based on joint scrutiny and covering economic and financial governance 'could gradually develop into an arena for political competition where battles are fought about the direction of the Union's economic policy. ${ }^{55}$ Instead of separate and disconnected debates on economic policy, the inter-parliamentary conference could help to constitute a transnational debate and promote transnational interests, although in the case of other transnational assemblies their contribution to the democratic legitimation of decision-making beyond the state is only marginal. ${ }^{56}$

\section{B. Ideal Types of Positions Towards Inter-Parliamentary Cooperation}

National parliaments have consciously adopted different positions towards interparliamentary cooperation. Resulting from their institutional self-interest, they generally prefer joint scrutiny to centralised scrutiny, but their preferences for the precise organisation of this kind of inter-parliamentary cooperation differ. On the basis of different levels of activity, this chapter proposes to classify the attitudes of national parliaments towards inter-parliamentary cooperation into three different roles: ${ }^{57}$ (1) inward-looking parliaments that rarely engage beyond the minimum requirements; (2) passively cooperative parliaments that participate in additional activities aimed at discussing inter-parliamentary cooperation; and (3) actively networking parliaments that try to build coalitions in order to bring interparliamentary cooperation forward.

53 Crum and Fossum, Conclusion (n 33) 253. See also the previous Section III of this chapter for the EP.

54 Curtin, 'Challenging Executive Dominance' (n 8) 29. See also Neunreither, 'The European Parliament and National Parliaments' (n 7).

55 Kreilinger (n 10) 23.

56 Kraft-Kasack, 'Transnational Parliamentary Assemblies' (n 19) 552.

57 These roles do not substitute other classifications of parliamentary involvement in EU affairs. The roles are rooted in national parliamentary practices in each Member State and based on divergent visions of what function(s) a legislature should perform. This classification has been inspired by classifications for national parliaments in other domains, namely O Rozenberg and C Hefftler, 'Introduction' in Claudia Hefftler et al (eds), Handbook of National Parliaments and the European Union (Basingstoke, Palgrave Macmillan, 2015) and C Sprungk, 'A New Type of Representative Democracy? Reconsidering the Role of National Parliaments in the European Union' (2013) 35 Journal of European Integration 547 , but the classification put forward in this chapter uses different categories and different distinctive features. 
The three roles of national parliaments in inter-parliamentary cooperation are defined as follows:

(1) Inward-looking parliaments rarely engage in inter-parliamentary cooperation beyond the minimum requirements. ${ }^{58}$ They put their priorities on the domestic arena. Such parliaments could be seen as 'gatekeepers' ${ }^{59}$ that have the objective, for example, to prevent legislation at the national level rather than shape it at the European level or see themselves as a national 'public forum. ${ }^{60}$ They are not Europeanised in their attitude towards interparliamentary cooperation, but can be Europeanised in other activities related to EU affairs.

(2) Passively cooperative parliaments that participate in additional activities aimed at discussing inter-parliamentary cooperation dedicate some additional resources to cooperation with their fellow parliaments, but do not try to set the agenda. Only when it is necessary, do they articulate their preferences on the precise organisation of inter-parliamentary cooperation. They send delegations to inter-parliamentary conferences comprising MPs that represent government and opposition parties and both chambers, if applicable. These parliaments are Europeanised as passive 'European players', ${ }^{61}$ so they could belong to this ideal type for general parliamentary involvement, but need not. Compared with parliaments that are inward-looking, they better understand the negotiation situation at the EU level.

(3) Actively networking parliaments try to build coalitions in order to influence the organisation of inter-parliamentary cooperation and have a network 'beyond their own domestic parliamentary arena.' ${ }^{62}$ Such a parliament organises extraordinary meetings with like-minded parliaments; it performs a 'networking role'63 with other parliaments (as well as supranational institutions) in an active way and could be seen as a 'European player'64 in the domain of inter-parliamentary cooperation. In comparison with parliaments that are only passively cooperative, they are able to coordinate themselves more easily with their counterparts. Europeanisation has affected actively networking parliaments differently. They can be suspicious of giving a greater role to the $\mathrm{EP}^{65}$ or including it in inter-parliamentary cooperation beyond the absolute minimum and could ultimately even imagine pursuing cooperation among national parliaments outside the EU treaties. ${ }^{66}$

58 For this analysis, 'minimum requirements' means participation in the Inter-parliamentary conference on Economic and Financial Governance.

59 Sprungk, 'A New Type of Representative Democracy?' (n 57).

60 Rozenberg and Hefftler, 'Introduction' (n57) 33.

61 ibid.

62 Rozenberg and Hefftler, 'Introduction' (n 60) 34.

63 Sprungk, 'A New Type of Representative Democracy?' (n 59) 551.

64 Rozenberg and Hefftler, 'Introduction' (n 60) 34.

65 T Winzen, C Roederer-Rynning and F Schimmelfennig, 'Parliamentary Co-evolution: National Parliamentary Reactions to the Empowerment of the European Parliament' (2015) 22 Journal of European Public Policy 75.

${ }^{66}$ For such a scenario, see Kreilinger (n 27) 67. 


\section{Examples of Positions of National Parliaments Towards Inter-Parliamentary Cooperation}

In order to illustrate the different positions that national parliaments may have on inter-parliamentary cooperation, this sub-section considers in detail the stance adopted by the parliaments of Denmark, France, Germany and Lithuania during the negotiations on the inter-parliamentary conference for economic and financial governance. The activities and preferences of each parliament are analysed and subsequently classified into the categories above.

In the negotiations on the conference of Article 13 TSCG, the Danish Folketing, the French Assemblée Nationale, the German Bundestag and the Lithuanian Seimas have all played important roles and adopted strong and visible positions. ${ }^{67}$ At the same time, the set of these four countries combines different degrees of parliamentary strength in EU affairs, big and small, old and new Member States and, as of 1 January 2015, three of these countries have the euro as their currency. This sub-section seeks to answer what their preferences have been and which roles these parliaments follow in their attitudes towards the inter-parliamentary conference in economic and financial governance.

\section{Denmark (Folketing)}

In Denmark, the national parliament is generally seen as the true source of legitimacy (compared to the EP): both its scrutiny system on EU legislation and the European affairs committee are very strong. ${ }^{68}$

The Danish Parliament has had a visible position in the discussions on the new inter-parliamentary conference based on Article 13 TSCG. ${ }^{69}$ In November 2012 and in March 2013 the chair of the European affairs committee organised meetings with her counterparts. At their second meeting the chairpersons of European affairs committees from 15 Member States gathered in Copenhagen and declared their preference for 'establishing a small effective conference focused on substantial issues - to be held in the margins of the biannual COSAC-meetings. ${ }^{\prime}{ }^{70}$ This could be interpreted as showing the institutional self-interest of European affairs committees to keep control over EMU issues and avoid empowering their fellow MPs who are most likely to come from budget, finance and economic committees in the case of the Article 13 TSCG inter-parliamentary conference, but it shows above all that the Folketing articulated its preferences and succeeded in building a large coalition.

67 See Cooper (n 9) and Kreilinger (n 10).

68 Winzen, Roederer-Rynning and Schimmelfennig, 'Parliamentary Co-evolution' (n 65) 9. See, generally T Raunio and S Hix, 'Backbenchers Learn to Fight Back: European Integration and Parliamentary Government' (2000) 23 West European Politics 142.

69 The TSCG was signed and ratified by Denmark despite its opt-out from the euro.

${ }^{70}$ Chairpersons of European Affairs Committees, Joint letter to the Speakers' Conference (2013) available at: www.ipex.eu/IPEXL-WEB/dossier/files/download/082dbcc53dbcb6ed013e07d2d3 1930a6.do. 
Hence the Danish Parliament has been an actively networking parliament in order to pursue its objectives, adopting a reluctant position towards an ambitious institutional design of the inter-parliamentary conference. In general, however, it is probably best classified as a passively cooperative parliament due to a lack of resources for cooperation, ${ }^{71}$ and taking into account its only average participation rate in inter-parliamentary conferences. ${ }^{72}$

\section{France (Assemblée Nationale)}

The question of the role of the national parliaments in the EU has often been discussed in the French Assemblée Nationale. ${ }^{73}$ This 'can ... be understood as a consequence of the limited weight of the French Parliament within the domestic political system ${ }^{74}$ and allows some MPs to discretely articulate criticism about the EU. All political forces in France agree that the role of the national parliaments in the EU should be strengthened.

The French National Assembly was in favour of quickly establishing an interparliamentary conference and proposed following the model for CFSP and CSDP with six MPs per national parliament and 16 MEPs that would accompany and control the European Semester. ${ }^{75}$ The Speakers of Parliaments of the six founding Member States ${ }^{76}$ endorsed this idea at a meeting in Luxembourg in January 2013. ${ }^{77}$ For euro area matters, the French would even like to establish (within that conference) a 'Joint Conference Committee' composed of six MPs per national parliament from Member States whose currency is the euro and 16 MEPs as full members.

The Assemblée Nationale has doubtlessly been an actively networking parliament that has tried to strengthen its own position against the government by exploiting the opportunities at the EU level to achieve this. It has had the clear objective to establish a strong inter-parliamentary body in order to give national parliaments a voice against intergovernmental, but also supranational, EU institutions. The positions are, however, far beyond the status-quo of inter-parliamentary cooperation and it has been difficult to find allies that share these bold objectives.

\footnotetext{
${ }^{71} \mathrm{C}$ Hefftler, 'Inter-parliamentary Relations in the EU: What Drives National Parliaments' Participation in Cooperation beyond the Domestic Arena?' (UACES 44th Annual Conference, 2014) 10.

72 See Kreilinger (n 10) 5 (reporting data on COSAC).

73 See, eg O Rozenberg, 'Debating about Europe at the French National Assembly: The Failure of the Rhetoric of Unanimity' in C Wiesner, T Turkka and K Palonen (eds), Parliament and Europe Rhetorical and Conceptual Studies on their Contemporary Connections (Baden-Baden, Nomos, 2011).

${ }^{74}$ V Kreilinger, K Perepechay and O Rozenberg, 'France' in W Wessels et al (eds), Democratic Control in the Member States of the European Council and the Euro zone summits Annex 2: In-depth reports on 12 Member States (European Parliament, 2013).

75 Assemblée nationale, 'Rapport d'information sur le projet de loi de ratification du Traité sur la stabilité, la coordination et la gouvernance au sein de l'Union économique et monétaire' (25 September 2012).

76 Belgium, France, Germany, Italy, Luxembourg and the Netherlands.

77 National Parliaments, 'Luxembourg Working Paper of 11 January 2013' available at: www.ipex. eu/IPEXL-WEB/dossier/files/download/082dbcc53b70d1c2013ccdb9a8692a61.do.
} 


\section{Germany (Bundestag)}

While Germany and its parliament have always been among the most vocal supporters of the $\mathrm{EP},{ }^{78}$ the Bundestag and Bundesrat were able to gain significant scrutiny powers with the treaty revisions of Maastricht (1993) and Lisbon (2009), mostly in reaction to decisions by the German Constitutional Court, which have significantly strengthened national scrutiny procedures. ${ }^{79}$

In the discussions around the inter-parliamentary conference of Article 13 TSCG, German MPs presented their ideas, but the Bundestag as a whole did not articulate an institutional position. ${ }^{80}$ The German Parliament was present at the meeting in Luxembourg in January 2013 and thus endorsed the working paper. Only at a very late stage, in the run-up to the first meeting of the conference in Vilnius in October 2013, the German position was made clear: It would be 'premature' to seek the adoption of Rules of Procedure at that point, but the delegation welcomed the idea to discuss the aims and functions of the conference. ${ }^{81}$ Although there is a strong participation in inter-parliamentary conferences and significant resources are available, ${ }^{82}$ unlike the French Assemblé Nationale, the German Bundestag has not been interested in establishing an inter-parliamentary conference on economic affairs quickly and has insisted on limiting the conference to being an advisory body. ${ }^{83}$

As a consequence, the German Parliament was initially, until autumn 2013, an inward-looking parliament, before turning into a passively cooperative parliament which-despite having strong opinions on the subject-did not seek to build coalitions. This is rather surprising, because having in mind the pro-European stance of the German Parliament and its strong powers, one could have expected it to be a strong supporter of inter-parliamentary cooperation in economic and financial governance. But the passive attitude of the German Bundestag may be explained in light of the significant domestic powers of oversight in EU and EMU affairs it has acquired as a result of recent judgments of the German Constitutional Court.

\section{Lithuania (Seimas)}

The Lithuanian Parliament, as parliament of the country holding the rotating Council presidency in the second half of 2013, and selected to chair the first meeting of the Inter-parliamentary Conference on Economic and Financial Governance taking place in Vilnius in October 2013, was in a special situation.

78 See Winzen, Roederer-Rynning and Schimmelfennig (n 65) 12.

79 C Callies and T Beichelt, Auf dem Weg zum Europäisierten Bundestag: Vom Zuschauer zum Akteur (Gütersloh, Bertelsmann Stiftung, 2013).

${ }^{80}$ See Deubner (n 10) 48.

${ }^{81}$ Bundestag, 'Letter by the Head of the German delegation, Norbert Barthle' (2013) available at: http://renginiai.lrs.lt/renginiai/EventDocument/0f6147e3-6125-40b9-93d8-edc7c31e085f/Barthle_ Lithuanian\%20Presidency_EN_courtesy\%20translation.pdf.

${ }^{82}$ Hefftler, 'Inter-parliamentary Relations' (n 71) 13.

${ }^{83}$ Bundestag, 'Letter by the President, Norbert Lammert' (2014) available at: www.ipex.eu/IPEXLWEB/dossier/files/download/082dbcc5452b142001456a262f7335a9.do. 
Although the time for preparing the first conference was limited, the Lithuanian Parliament prepared a draft of the Rules of Procedure:

The Seimas had tentatively scheduled time during the Vilnius conference for the draft to be debated and, at the end, adopted. Some parliaments commended the efforts of the Seimas in preparing it, and a number of delegations (from Estonia, France, Poland and the UK) proposed amendments to the draft, on the presumption that this document would provide the basis for the debate in Vilnius. ${ }^{84}$

But the Bundestag and the EP succeeded in exerting pressure on the Lithuanian Parliament to remove the item from the agenda of the conference. The debate about how conclusions to be adopted at the end of the conference should be called and the way in which the Lithuanian Parliament managed to achieve its goals shows that it was able to use the prerogatives of the presidency. ${ }^{85}$

The Seimas has been actively networking in its Presidency function, but may have underestimated that some parliaments were just not interested in agreeing on Rules of Procedure at the first conference. It remains to be seen whether the Lithuanian Parliament will be an equally active European player after the semester during which it presided over inter-parliamentary cooperation: Even if the participation of the Lithuanian Parliament in COSAC is in line with that of other national parliaments, ${ }^{86}$ it can be assumed that its resources are limited.

In summary, national parliaments showed different preferences on the precise organisation of the inter-parliamentary conference on economic governance foreseen by Article 13 TSCG. Most national parliaments prefer joint scrutiny to centralised scrutiny, due to their institutional self-interest. They have consciously adopted positions and articulated them to their peers. These positions are based on broader attitudes towards inter-parliamentary cooperation which can be classified according to three different roles (inward-looking parliaments, passively cooperative parliaments, actively networking parliaments): The Danish Folketing was actively networking, but might not always be able to pursue this strategy and more often acts as a passively cooperative body; the German Bundestag was inward-looking, but turned into a passively cooperative parliament; the French Assemblée Nationale was actively networking; and, finally, the Lithuanian Seimas took the privilege of its six-month presidency seriously and was actively networking during that period of time. The resources that are available in a national parliament seem to affect the extent of inter-parliamentary activities. Besides that, the motivation of the individual MP to participate is a factor that might also play an important role. ${ }^{87}$ Parliamentarians have to juggle between commitments linked to (national) party, (local) constituency, the domestic political arena and international activities, like inter-parliamentary cooperation. Research has shown that the importance which

84 Cooper (n 9) 20.

85 See ibid.

86 See Kreilinger (n 10) 5.

87 See, eg C Deubner and V Kreilinger, The Role and Place of Parliaments in a Genuine Economic and Monetary Union (Notre Europe-Jacques Delors Institute, 2013). 
individual MPs attribute to the EU for the success of their work has a significant effect on their activities to obtain EU-related information. ${ }^{88}$

Beyond the four national parliaments that were analysed here, a larger study gathering more data and covering more parliaments could provide additional insights. Many of the national parliaments that were not clearly articulating their positions, might in fact be inward-looking parliaments and constitute a silent group of national parliaments that carries the responsibility for the absence of a collective position related to inter-parliamentary cooperation.

\section{CONCLUSION: PROSPECTS FOR THE RELATIONSHIP BETWEEN NATIONAL PARLIAMENTS AND THE EUROPEAN PARLIAMENT IN THE AREA OF FINANCIAL AND ECONOMIC GOVERNANCE}

Article 13 TSCG foresaw the creation of an inter-parliamentary conference on budgetary policies and other issues covered by that treaty, but diverging preferences among national parliaments and reluctance from the EP concerning the internal organisation of the conference have so far prevented a smooth implementation of the provision. Deadlock, in particular, has emerged with regard to the adoption of the Rules of Procedure. Inter-parliamentary cooperation is not a new idea and the model of the CFSP/CSDP inter-parliamentary conference seems to be well-suited to the goal of having representatives from all major political parties and specialised MPs (like committee chairs) in each delegation.

Inter-parliamentary cooperation in economic and financial governance faces challenges because the relationship between the two parliamentary levels (centralised scrutiny or joint scrutiny) has not been clearly defined until now: 'centralised scrutiny' would mean that scrutiny is dominated by the EP, with only very limited input by national parliaments; whereas with 'joint scrutiny' national parliaments and the EP would cooperate more closely. ${ }^{89}$ The EP and the other EU institutions prefer centralised scrutiny and many of their contributions in the negotiations on the implementation of Article 13 TSCG show that their objective has been to keep the inter-parliamentary conference, as an element of joint scrutiny, weak. Inter-parliamentary cooperation does, however, work more or less well in other policy areas: with a 'legal-constitutional status' ${ }^{90}$ in the cases of the two other inter-parliamentary conferences, and without such a status in many ad-hoc inter-parliamentary meetings. ${ }^{91}$ The explanation for the current deadlock seems to be the same as for the challenges which the inter-parliamentary conference on CFSP/CSDP had been facing: 'overlapping authority claims. ${ }^{92}$ But in the case of

${ }^{88}$ A Wonka, B Rittberger, 'The Ties that Bind? Intra-party Information Exchanges of German MPs in EU Multi-level Politics' (2014) 37 West European Politics 624.

89 Cooper (n 9) 2.

90 Cooper (n 9) 23.

91 Kreilinger (n 10) 7.

92 Herranz-Surrallés (n 6) 15. 
CFSP/CSDP the changes had taken place step-by-step over a longer time period since the Maastricht Treaty (1993) than in the case of EMU where the real losses of sovereignty only took place with 'six-pack', TSCG and 'two-pack' (2011-2013). In CFSP/CSDP establishing an inter-parliamentary conference was debated in the 2000s; in economic and financial governance in 2013-14, only a few months after the changes had taken place.

This chapter has examined the preferences of the most important actors in the negotiations on the inter-parliamentary conference on economic and financial governance. Its two most vocal critics see a mixed parliamentary body as ineffective and illegitimate' (EP) or want to reduce it to an 'advisory role' (German Bundestag) Other national parliaments have been more active in inter-parliamentary cooperation and more supportive of the inter-parliamentary conference than the German parliament which was for a long time inward-looking and only became passively cooperative in late 2013. This chapter has also examined preferences and attitudes of the parliaments of Denmark, France and Lithuania in detail and classified their roles as alternating between actively networking and passively cooperative (Danish Folketing and Lithuanian Seimas) and actively networking (French Assemblée Nationale). Many other national parliaments which did not articulate their positions clearly, might be inward-looking parliaments with little interest in inter-parliamentary cooperation. In general, national parliaments prefer joint scrutiny to centralised scrutiny dominated by the EP, but have not been able to agree on a common position. The current deadlock means that much of the determination to establish some kind of powerful inter-parliamentary control has been lost. Thus one can say that parliaments have, once again, failed to be a collective actor at the EU level. ${ }^{93}$

The EU-related democratic deficit at the national level which was reduced in the 1990s when most national parliaments established institutions and mechanisms that forced governments to explain their actions and policies at the EU level, ${ }^{94}$ seems to be much bigger in the case of fiscal and economic policy coordination than in EU affairs in general. ${ }^{95}$ The Euro-crisis and the response to it have put national governments at the centre of EU policy making and parliamentary actors are standing at the sidelines. Thus it still seems possible that two parliamentary levels could work together against their declining influence, 'exert countervailing power', 96 'discuss' matters of common interest and 'control' in areas with weak parliamentary scrutiny (but not'decide'). The key activity of an inter-parliamentary conference lies in its capacity to scrutinise rather than in taking binding decisions: 'European decision-makers should be publicly heard, questioned and even

93 Kreilinger (n 10) 17.

94 Raunio and Hix, 'Backbenchers Learn to Fight Back' (n 68).

95 See especially Chalmers (n 4); Dehousse and Boussaguet, R Dehousse and L Boussaguet, 'L'impact de la crise' (n 45); Scharpf, 'Monetary Union' (n 45).

96 Curtin (n 8) 30. 
criticised by the conference. ${ }^{97}$ If the Inter-parliamentary Conference on Economic and Financial Governance acquired decision-making power, this would significantly alter the institutional equilibrium. The 2014 Speakers' Conference stated that:

Although the role, scope and title of the Conference are yet to be defined, it is clear at this point that the Conference can serve as a useful parliamentary forum to discuss and exchange ideas, information, and best practice. Speakers consider that the Conference could have its own Rules of Procedure and may adopt non-binding conclusions. ${ }^{98}$

To sum up, inter-parliamentary control would help reduce the existing weakness in democratic accountability and legitimacy linked to the genuine EMU in the making. The question 'What form of government for the EU and the Eurozone?' that this volume is asking, also raises the question about parliamentary control: 'whenever an issue concerns the currency, taxation or the welfare system, parliament must be brought into the debate in one way or another'. ${ }^{99}$ National parliaments were seen as the 'losers or latecomers' ${ }^{100}$ on their way to Europe. In the case of inter-parliamentary control of the EMU they still have to overcome some challenges that were outlined in this chapter and learn 'to fight back'101 against the executives.

97 V Kreilinger and O Rozenberg, 'The Inter-parliamentary Conference on Economic and Financial Governance' in House of Lords (ed), The Role of National Parliaments in the European Union. Written Evidence (2013), available at: www.parliament.uk/documents/lords-committees/eu-select/Role\%20 of $\% 20$ national\%20parliaments/nat-parl-evidence-volume.pdf, 118 .

98 Conference of Speakers of European Union Parliaments, 'Presidency Conclusions_-Vilnius, 6-8 April 2014' available at: www.ipex.eu/IPEXL-WEB/dossier/files/download/082dbcc5452b1420014541 dc98d61251.do.

99 J Delors, Rethinking the EMU and Making the Greater Europe Positive Again (Notre EuropeJacques Delors Institute, 2013) 4.

100 A Maurer and W Wessels, National Parliaments on Their Ways to Europe: Losers or Latecomers? (Baden-Baden, Nomos, 2001).

101 Raunio and Hix (n 68). 